\title{
C/N RATIO AND NUTRIENT CONTENT IN PEACH BARK RELATED TO PEACH TREE SHORT LIFE ${ }^{1}$
}

\author{
NEWTON ALEX MAYER ${ }^{2}$, BERNARDO UENO², VALÉCIA ADRIANA LUCAS DA SILVA ${ }^{3}$, \\ RICARDO ALEXANDRE VALGAS ${ }^{2}$, CRISTINA MOREIRA DA SILVEIRA ${ }^{4}$
}

\begin{abstract}
Peach Tree Short Life (PTSL) is a syndrome characterized by a plant collapse at the end of dormancy, which causes include several biotic and abiotic components. The aim of this study was to assess the $\mathrm{C} / \mathrm{N}$ ratio and bark nutrients in symptomatic and asymptomatic short-life peach trees. Live tissue portions were removed from the bark of the main scaffolds of symptomatic and asymptomatic adjacent trees in nine commercial peach orchards located in Pelotas and Canguçu, state of Rio Grande do Sul, Brazil. In laboratory, carbon $(\mathrm{C})$, nitrogen $(\mathrm{N})$, phosphorus $(\mathrm{P})$, potassium $(\mathrm{K})$, calcium $(\mathrm{Ca})$, magnesium $(\mathrm{Mg})$, iron $(\mathrm{Fe})$, manganese $(\mathrm{Mn})$, zinc $(\mathrm{Zn})$, copper $(\mathrm{Cu})$, boron $(\mathrm{B})$ contents and $\mathrm{C} / \mathrm{N}$ ratio were determined. The main component analysis of the study variables did not allow the formation of different groups between symptomatic and asymptomatic short-life peach trees. Peach trees with visible PTSL symptoms had higher $\mathrm{N}, \mathrm{P}$ and $\mathrm{K}$ contents and lower $\mathrm{C} / \mathrm{N}$ ratio in the bark of the main scaffolds in the early sprouting season.
\end{abstract}

Index terms: nutrient, nutrition, PTSL syndrome, Prunus spp., Rosaceae.

\section{RELAÇÃO C/N E TEORES DE NUTRIENTES NA CASCA DE PESSEGUEIROS RELACIONADOS COM A MORTE PRECOCE}

RESUMO-A morte precoce do pessegueiro é uma síndrome caracterizada por um colapso das plantas no final do período de dormência, cujas causas envolvem diversos fatores bióticos e abióticos. No presente trabalho, objetivou-se avaliar a associação da morte precoce com a relação carbono/nitrogênio $(\mathrm{C} / \mathrm{N})$ e os teores de nutrientes presentes na casca das plantas. Porções de tecido vivo foram removidas da casca das pernadas principais das plantas sintomáticas e nas respectivas plantas adjacentes assintomáticas, em nove pomares comerciais localizados nos municípios de Pelotas e Canguçu, no Rio Grande do Sul. Em laboratório, foram determinados os teores de carbono $(\mathrm{C})$, nitrogênio $(\mathrm{N})$, fósforo $(\mathrm{P})$, potássio $(\mathrm{K})$, cálcio $(\mathrm{Ca})$, magnésio $(\mathrm{Mg})$, ferro $(\mathrm{Fe})$, manganês $(\mathrm{Mn})$, zinco $(\mathrm{Zn})$, cobre $(\mathrm{Cu})$, boro $(\mathrm{B})$ e a relação $\mathrm{C} / \mathrm{N}$. Conclui-se que a análise de componentes principais das variáveis estudadas não possibilitou a formação de grupos distintos entre plantas sintomáticas e assintomáticas de morte precoce do pessegueiro. Pessegueiros com sintomas visíveis de morte precoce apresentam maiores níveis de N, P e K, e menor relação $\mathrm{C} / \mathrm{N}$ na casca das pernadas principais, no período de início de brotação.

Termos para indexação: nutriente, nutrição, síndrome, Prunus spp., Rosaceae.

\footnotetext{
${ }^{1}$ (Paper 115-15). Received May 08, 2015. Accepted November 26, 2015.

${ }^{2}$ Researcher at Embrapa Temperate Agriculture, BR 392, km 78, P.O. box 403, CEP 96010-971, Pelotas-RS. E-mails: alex.mayer @ embrapa.br; bernardo.ueno@embrapa.br; ricardo.valgas@embrapa.br

${ }^{3}$ Degree in Biological Sciences at the Catholic University of Pelotas (UCPel), PIBIC / CNPq scholarship. E-mail: valecia_adriana @ hotmail.com

${ }^{4}$ Analyst at the Embrapa Temperate Agriculture. E-mail: cristina.silveira@embrapa.br
} 


\section{INTRODUCTION}

Peach tree short life (PTSL) is a syndrome that involves several biotic and abiotic factors and occurs in young plants, usually between one and eight years old. The first symptoms in the plant are visible in winter or early spring when, before or after the onset of flowering and sprouting, there is a breakdown in the plant, with necrosis and sour odor under the bark of branches, growth reduction or stoppage, as evidenced by the decrease or lack of sprouting and flowering. The death of buds, shoots, plant parts or even the entire canopy is also observed. Some roots are also necrotic, but usually the rootstock remains alive. Affected plants may be isolated or in kriging, both in the higher or lower parts of orchards (BRITTAIN; MILLER Jr., 1978; RITCHIE; CLAYTON, 1981; MAYER et al., 2009; CAMPOS et al., 2014). Although the occurrence of PTSL in areas previously cultivated with peach is more common (RITCHIE; CLAYTON, 1981), studies have shown that the syndrome can occur in areas never planted with the crop (NYCZEPIR, 1990; NYCZEPIR; OKIE, 1996).

In Brazil, peach tree short life was firstly found in late 1970s by Emater technicians in the peach producing region of Pelotas-RS. Since then, the onset of symptoms has been quite variable from one year to another, but is intensifying especially in the regions of Pelotas and Campanha Gaúcha where, in more severe cases, orchards with up to $90 \%$ of symptomatic plants were found (MAYER et al, 2009;. MAYER, UENO, 2012). In nematode survey carried out in 20 orchards of the hillside region of southeastern Rio Grande do Sul, Mesocriconema xenoplax was the only nematode present in $100 \%$ of samples and populations between 1,000 and 3,000 nematodes $/ 100 \mathrm{~cm}^{3}$ soil were positively correlated with peach tree short life symptoms (CARNEIRO et al., 1993). Symptomatic PTSL plants present decreased percentage of soluble carbohydrates at the beginning of sprouting, and abrupt reduction in starch content in buds in the pre-flowering stage (CAMPOS, 1992; HERTER; MARAFON, 2007). However, for peroxidase activity, the results were divergent among authors (CAMPOS, 1992; HERTER; MARAFON, 2007).

There are several factors reported in literature as causes or factors that predispose plants to the occurrence of this syndrome. Anatomical anomalies and reduced production of vessels in new branches, parasitism of ring nematode Mesocriconema xenoplax, bacterial canker caused by Pseudomonas syringae pv. syringae and the use of susceptible rootstocks are cited as biotic factors. Low soil $\mathrm{pH}$, high aluminum and sulfur sulfate concentrations in the soil, sandy loam texture, injuries caused by cold, temperature fluctuations in the winter, physical soil constraints, physical damage to roots caused by harrows and plows, early pruning in the fall and inadequate cultural practices are cited as abiotic factors (JONES; JONES, 1974; BRITTAIN; MILLER Jr., 1978; WEHUNT et al., 1980; RITCHIE; CLAYTON, 1981; REILLY et al., 1986; NYCZEPIR, 1990; OKIE et al., 1994; WERNER et al., 1995; MARAFON et al., 2009; LUNA-GUERRERO et al., 2011). Mechanisms involved in plant resistance to cold (total soluble sugars, sucrose and expression of $ß$-amylase gene) and adaptation of cultivars to temperature fluctuations in winter-spring have been recently studied (SHIN et al., 2015a .; SHIN et al., 2015b.).

In three-year-old 'Maycrest' / 'Nemaguard' peach, Muñoz et al. (1993) found that during the flowering and fruit set period, only $7 \%$ of $\mathrm{N}$ found in new growth came from fertilizer and the rest $(93 \%)$ originated from $\mathrm{N}$ stored in older organs (barks and wood branches, trunk, thin, thick and fibrous roots), showing the importance of storage organs of plants. Analysis of bark collected from the central portion of one-year-old dormant branches devoid of buds revealed that the $\mathrm{Fe}, \mathrm{K}$ contents and the $\mathrm{K} / \mathrm{Ca}$ ratio are good iron deficiency indicators in 'Maycrest' peach trees grown in alkaline soils (ALMALIOTIS et al., 1995). In orange trees 'Pera' [Citrus sinensis (L.) Osbeck], nutrient levels evaluated in the bark and trunk wood, bark and root wood, leaves and fruits showed no significant differences between healthy and symptomatic citrus plants with chlorosis caused by Xylella fastidiosa. However, considering the average nutrient content of all plant components analyzed, plants with the presence of $X$. fastidiosa had lower N, P and Mn levels (RICCI et al., 2001).

Healthy peach branches and leaves have lower $\mathrm{Al}, \mathrm{Fe}$ and $\mathrm{Ca}$ contents compared to plants with PTSL symptoms (JONES; JONES, 1974). In this study, the authors found that $\mathrm{Fe}$ : $\mathrm{Al}$ ratio of 1: 1 was associated with terminal branches collected from plants killed by the syndrome; Fe: Al ratio of 1 : 1.5 was associated with leaves collected from plants partially affected by the syndrome; and Fe: Al ratio of 1: 0.75 was associated with leaves from healthy plants. Sharpe and Reilly (1986) agree only with the smallest $\mathrm{Al}$ and $\mathrm{Fe}$ levels observed in leaves and branches from healthy plants. However, according to these authors, Ca levels were lower in leaves of infected PTSL plants (and not in healthy plants, as previously reported) and the $\mathrm{Fe}$ : Al ratio was not 
consistent to associate this variable to healthy plants or those with PTSL symptoms. In addition, when analyzing the trunk bark of healthy and symptomatic plants, the only statistical difference observed (K content) showed opposite results between orchards.

Considering that inadequate plant nutrition (SHARPE et al., 1989) and high $\mathrm{C} / \mathrm{N}$ ratio (CAO et al., 2005) have been mentioned as factors that may favor the occurrence of PTSL and lack of information on the subject in Brazilian literature, this study was aimed to evaluate the association of PTSL with the $\mathrm{C} / \mathrm{N}$ ratio and nutrient content in peach bark in nine commercial orchards in the region of Pelotas.

\section{MATERIAL AND METHODS}

Bark samples from main scaffolds of peach trees were collected in nine commercial orchards in the municipalities of Pelotas and Canguçu, southern state of the Rio Grande do Sul between August 15 and September 13, 2013. The main features of these orchards such as location, minimum and maximum orchard altitude, land slope direction, cultivar, rootstock and plant age are shown in Table 1. Sampled orchards had area between 0.3 and 1.5 ha and were within the same homogeneous plot of their farms. During the sampling period, plants with PTSL symptoms could be easily identified by the typical symptoms of the syndrome (BRITTAIN; MILLER Jr., 1978; CAMPOS et al., 2014).

In each orchard, five to seven pairs of symptomatic and asymptomatic PTSL plants were sampled, which were located side-by-side (paired) in the same planting row distant 1.5 to $3 \mathrm{~m}$ from each other. Eventually, plants suitable for sampling could not be found in the same planting row, then using an adjacent plant in the next planting row, distant 4 to 6 meters from each other. With the aid of a knife, several portions of the living tissue of the outer bark were collected along with the inner bark (up to reaching the wood) from the main scaffolds of symptomatic plants at height between 0.5 and 1.2 $\mathrm{m}$ from ground level, totaling from 6 to $10 \mathrm{~g}$ fresh weight per plant. The same sampling methodology was adopted for the adjacent asymptomatic plant. Samples were packed in plastic bags and identified with numbers in ascending order, being odd numbers for asymptomatic plants (54 samples) and pair numbers for symptomatic plants (54 samples).

In laboratory, samples were cut with the aid of scissors into pieces of approximately $0.5 \mathrm{~cm}^{2}$, transferred to paper bags and dried at $65^{\circ} \mathrm{C}$ for $72 \mathrm{~h}$. Samples were ground in De Leo Wiley mill with $0.5 \mathrm{~mm}$ sieve (= $35 \mathrm{mesh})$ and stored in plastic vials at room temperature. For $\mathrm{P}, \mathrm{Ca}, \mathrm{Mg}$ and $\mathrm{K}$ determination, digestion with $\mathrm{H}_{2} \mathrm{O}_{2}$ and $\mathrm{H}_{2} \mathrm{SO}_{4}$ mixture was performed (TEDESCO, 1995). The $\mathrm{P}$ content was determined by the ammonium molybdate and aminonaphtolsulfonic acid method in spectrophotometer at $660 \mathrm{~nm}$. The standard curve used had $\mathrm{P}$ concentrations between 1.0 and 10.0 $\mathrm{mg} \mathrm{L}{ }^{-1}$. $\mathrm{Ca}$ and $\mathrm{Mg}$ contents were determined by reaction of the digestion extract with $0.1 \%$ lanthanum oxide in Flame Atomic Absorption Spectrometer (Varian AA204FS) at wavelength of $422.7 \mathrm{~nm}$ for $\mathrm{Ca}$ and $285.2 \mathrm{~nm}$ for $\mathrm{Mg}$ (VARIAN, 2006). For $\mathrm{Ca}$ quantification, standard curve with concentration from 1.0 to $8.0 \mathrm{mg} \mathrm{L}^{-1}$ and standard curve with concentration from 0.2 to $1.0 \mathrm{mg} \mathrm{L}^{-1}$ for $\mathrm{Mg}$ were used. $\mathrm{K}$ was quantified by diluting the digestion extract in Flame Atomic Absorption Spectrometer in atomic emission mode at wavelength of $766.5 \mathrm{~nm}$. Standard curve with concentration from 0.8 to 10.0 $\mathrm{mg} \mathrm{L} \mathrm{L}^{-1}$ was used.

For $\mathrm{Cu}, \mathrm{Fe}, \mathrm{Mn}$ and $\mathrm{Zn}$ determination, nitroperchloric digestion was performed as Tedesco (1995). Reading in Flame Atomic Absorption Spectrometer was directly carried out in the digestion extract. The wavelengths used were $324.7 \mathrm{~nm}$ for $\mathrm{Cu}, 248.3 \mathrm{~nm}$ for $\mathrm{Fe}, 279.5 \mathrm{~nm}$ for $\mathrm{Mn}$ and 213.9 $\mathrm{nm}$ for Zn (VARIAN, 2006). A mixed standard curve with concentrations from 10 to $40 \mathrm{mg} \mathrm{L}^{-1}$ of copper, 100 to $400 \mathrm{mg} \mathrm{L}^{-1}$ of iron, 100 to $400 \mathrm{mg}$ $\mathrm{L}^{-1}$ of manganese and 25 to $100 \mathrm{mg} \mathrm{L}^{-1}$ of zinc was used. The $\mathrm{B}$ determination was made by reaction with 3: 1 azomethine buffer solution after sample calcination in a muffle furnace. Quantification was performed on spectrophotometer at $435 \mathrm{~nm}$ using a standard curve with concentrations from 0.25 to $2.50 \mathrm{mg} \mathrm{L}^{-1}$ (TEDESCO, 1995). Finally, $\mathrm{C}$ and $\mathrm{N}$ determination was carried out using the Elementar TruSpec CHN Analyzer equipment (LECO). The firing temperatures followed manufacturer's recommendations (LECO, 2005).

Data were submitted to principal component analysis (JOHNSON; WICHERN, 2007) to identify the joint relationship among study variables and to verify the distribution of plant groups with and without symptoms, based on the main components. Then, plant groups were individually evaluated for each variable through analysis of variance (ANOVA), considering 95\% confidence. Analyses were performed using the " $\mathrm{R}$ " software and graphics were generated by the "MINITAB 14" software. 


\section{RESULTS AND DISCUSSION}

According to the principal component analysis, it was found that the percentage of the total data variation explained by the first two principal components is $51.7 \%$ (data not shown). It was observed that $\mathrm{K}, \mathrm{P}$ and $\mathrm{N}$ nutrients, and more weakly $\mathrm{Mg}$, have a correlation (Figure 1). B, Fe, $\mathrm{Zn}, \mathrm{Mn}$ and, more weakly $\mathrm{Ca}$, are also correlated, but have no relation with previous mentioned nutrients. The low explanation percentage provided by the first two components decreases the likelihood of observing the formation of two distinct groups, between symptomatic and asymptomatic plants. The scores obtained for each plant were recorded and, from them, a confounding between groups was observed (Figure 2). There is also a large group of symptomatic plants with high values in component 1 , which shows high $\mathrm{N}, \mathrm{P}$ and $\mathrm{K}$ concentrations and low concentrations for the other variables. Asymptomatic plants gather in component 2 with positive values, representing high $\mathrm{C}$ concentration and low $\mathrm{N}, \mathrm{P}$, $\mathrm{K}$, and $\mathrm{Mn}$ concentrations. Given these results, univariate analysis was performed to identify which chemical elements could distinguish plant groups.

Table 2 shows the mean followed by the standard error for each variable analyzed in each plant group. Statistically significant differences were found for N, C / N ratio, P and K. Symptomatic plants had significantly higher $\mathrm{N}, \mathrm{P}$ and $\mathrm{K}$ concentrations in the bark of the main scaffolds compared to asymptomatic plants. However, in symptomatic plants, it was observed that the $\mathrm{C} / \mathrm{N}$ ratio was significantly lower compared to asymptomatic plants (Table 2). This variable is influenced by the higher $\mathrm{N}$ content in symptomatic plants, as the average $\mathrm{C}$ contents did not differ between plant groups. The results obtained in this study for the $\mathrm{C} / \mathrm{N}$ ratio disagree with results shown by Cao et al. (2005). According to these authors, peach trees inoculated with ring nematode $M$. xenoplax show higher concentrations of total phenolic compounds and higher $\mathrm{C} / \mathrm{N}$ ratio in the bark of plants, as well as major cankers caused by Pseudomonas syringae pv. syringae, which are factors related to PTSL.

However, the present data agree with a recent study carried out in South Carolina, United States (REIGHARD et al., 2014), which adopted similar sampling methodology. According to these authors, the $\mathrm{N} \%$ was significantly higher in symptomatic plants in five of the seven sampled orchards. In the five orchards, the $\mathrm{C} / \mathrm{N}$ ratio was significantly lower in symptomatic plants in four orchards, suggesting that increases in $\mathrm{N}$ fertilization to reduce bacterial canker and PTSL may not be effective and even produce deleterious effects on the survival of plants. In fact, late nitrogen fertilization or very high $\mathrm{N}$ doses can make plants more sensitive to injuries caused by cold (MILLARD, 1995). These findings are also in accordance with Thomas and Blank (1996), who found reduced resistance to cold in oak trees (Quercus petraea and Q. robur) due to lower C / $\mathrm{N}$ ratio in the bark and leaves and also due to plant defoliation caused by pests. The authors concluded that reducing the resistance to cold is preceded by the occurrence of at least two of the following factors: excess nitrogen, drought and early plant defoliation.

For variables that showed significant differences ( $\mathrm{N}, \mathrm{P}, \mathrm{K}$ and $\mathrm{C} / \mathrm{N}$ ratio), scatter plots for data behavior viewing were prepared (Figure 3 ). It is observed that, for $\mathrm{N}, \mathrm{P}$ and $\mathrm{K}$, some symptomatic plants showed high concentrations of these nutrients, and therefore, there was an increase in average values of these nutrients compared to asymptomatic plants. These differences were significant between plant groups (Table 2) and agree with Sharpe et al. (1989). According to these authors, the $\mathrm{P}$ and $\mathrm{K}$ levels of terminal branches tended to be higher in plants with PTSL symptoms compared to healthy plants and the sampling carried out on April (shortly after the onset of visible PTSL symptoms), the N, Ca, Mg, Mn and Fe contents were higher in symptomatic plants. As samples were collected before and after the onset of PTSL symptoms, the authors found that the nutrient concentrations in the branches of healthy plants decreased between March and April, while in PTSL plants, concentrations remained virtually unchanged. These results showed that nutrients were mobilized from branches to new leaves much faster in healthy plants compared to PTSL plants. Probably, this fact has also occurred in this study, which may explain the lower N, P and K levels in healthy plants (Table 2). Due to the unpredictability occurrence of PTSL under the conditions in southern Brazil, especially due to climatic oscillations of winter, lack of standardization of rootstocks and differences in cultural practices among orchards, it was not possible to perform samplings before the onset of symptoms.

In deciduous fruits, nitrogen is stored during the winter, predominantly in the form of protein in the bark of branches and trunks, remobilizing it in the spring, when dormancy is broken (MILLARD, 1995). Muñoz et al. (1993) demonstrated the N distribution in the various components of threeyear-old 'Maycrest' / 'Nemaguard' peach trees in monthly evaluations throughout the year. At the onset of sprouting (March in the northern hemisphere), the average total nitrogen content of 
plants was 14.9 g plant $^{-1}$ and, of this total, $8.99 \%$ and $12.55 \%$ were found in the bark of branches and trunks, respectively. Foliar applications of $\mathrm{Ca}\left(\mathrm{NO}_{3}\right)_{2}$ increase concentrations of nitrogen in peach leaves and calcium in peach bark, but showed no effect in reducing susceptibility to infection by Pseudomonas syringae pv. syringae (CAO et al., 2013).

The absence of statistically significant differences in the nutrient content of terminal branches of PTSL and healthy plants before the visual appearance of symptoms led Sharpe et al. (1989) to conclude that none of the nutrients being assessed (N, $\mathrm{P}, \mathrm{K}, \mathrm{Al}, \mathrm{Ca}, \mathrm{Fe}, \mathrm{Mg}, \mathrm{Mn}$ and $\mathrm{Zn}$ ) were the cause, but were consequences of the syndrome. Differences in results between this study and literature (CAO et al.,
2005) may be due to the sampling time, tissue type, plant age and cultural practices, as already reported by Reighard et al. (2014). Additionally, it should be considered that all orchards sampled in this study had varietal mixtures of seeds of different scion cultivars as rootstock (Table 1); therefore, with unknown genetic identity, which may have influenced the nutrient content of the sampled tissue. In the plant nutrition area, the effects of the absence of postharvest fertilization, low levels of organic matter and the high solubility of nitrogen fertilizers could be investigated as potential factors that predispose plants to the occurrence of Peach Tree Short Life in southern Brazil.

TABLE 1 - Identification, location and main characteristics of nine peach orchards sampled. Embrapa Clima Temperado, 2014.

\begin{tabular}{|c|c|c|c|c|c|c|}
\hline Orchard & Location & $\begin{array}{l}\text { Altitude } \\
\text { (meters) }\end{array}$ & $\begin{array}{l}\text { Land slope } \\
\text { direction }{ }^{1}\end{array}$ & Scion Cultivar & Rootstock & $\begin{array}{l}\begin{array}{l}\text { Tree age } \\
\text { (years) }\end{array} \\
\end{array}$ \\
\hline Orchard 1 & $\begin{array}{l}\text { Colônia Santa Áurea, } \\
\text { 7th district of Pelotas }\end{array}$ & $156-167$ & $\mathrm{~N}$ and $\mathrm{NW}$ & Bonão & $\begin{array}{c}\text { Mixture of cultivars } \\
\text { obtained in canning } \\
\text { factories }\end{array}$ & 05 \\
\hline Orchard 2 & $\begin{array}{l}\text { Colônia Santa Áurea, } \\
\text { 7th district of Pelotas }\end{array}$ & $141-152$ & S & Bonão & Same & 03 \\
\hline Orchard 3 & $\begin{array}{l}\text { Colônia São Manoel, } \\
\text { 8th district of Pelotas }\end{array}$ & $242-248$ & NW & Bonão & Same & 05 \\
\hline Orchard 4 & $\begin{array}{l}\text { Colônia Dias, } \\
\text { 7th district of Pelotas }\end{array}$ & $117-123$ & SE & Sensação & Same & 08 \\
\hline Orchard 5 & $\begin{array}{l}\text { Colônia Santa Eulália, } \\
\text { 5th district of Pelotas }\end{array}$ & $144-148$ & $\mathrm{NE}$ & Maciel and Jade & Same & 02 \\
\hline Orchard 6 & $\begin{array}{l}\text { Colônia Santa Helena, } \\
\text { 8th district of Pelotas }\end{array}$ & $206-213$ & $\mathrm{~N}$ & $\begin{array}{l}\text { Chiripá, } \\
\text { Granada, } \\
\text { Eldorado and } \\
\text { Chimarrita }\end{array}$ & Same & 04 \\
\hline Orchard 7 & $\begin{array}{l}\text { Colônia Santa Helena, } \\
\text { 8th district of Pelotas }\end{array}$ & $225-233$ & SW & Jade & Same & 03 \\
\hline Orchard 8 & $\begin{array}{l}\text { Colônia Santa Clara, } \\
\text { 1st district of Canguçu }\end{array}$ & $302-325$ & W & Granito & Same & 05 \\
\hline Orchard 9 & $\begin{array}{l}\text { Colônia Rincão dos } \\
\text { Maia, 1st district of } \\
\text { Canguçu }\end{array}$ & $250-260$ & $\mathrm{NE}$ & Esmeralda & Same & 04 \\
\hline
\end{tabular}




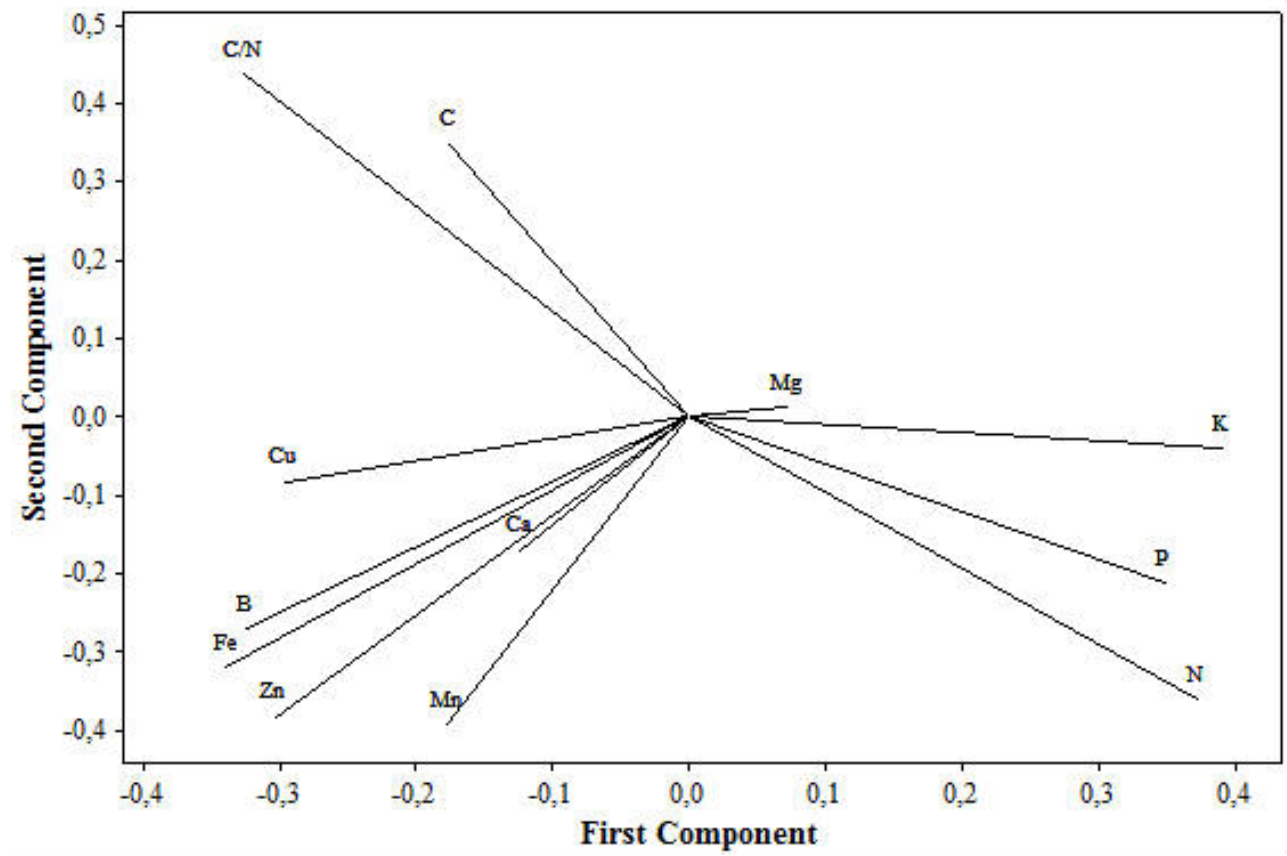

FIGURE 1- Principal component analysis of variables evaluated in the bark of symptomatic and asymptomatic PTSL peach trees. Embrapa Clima Temperado, February 2015.

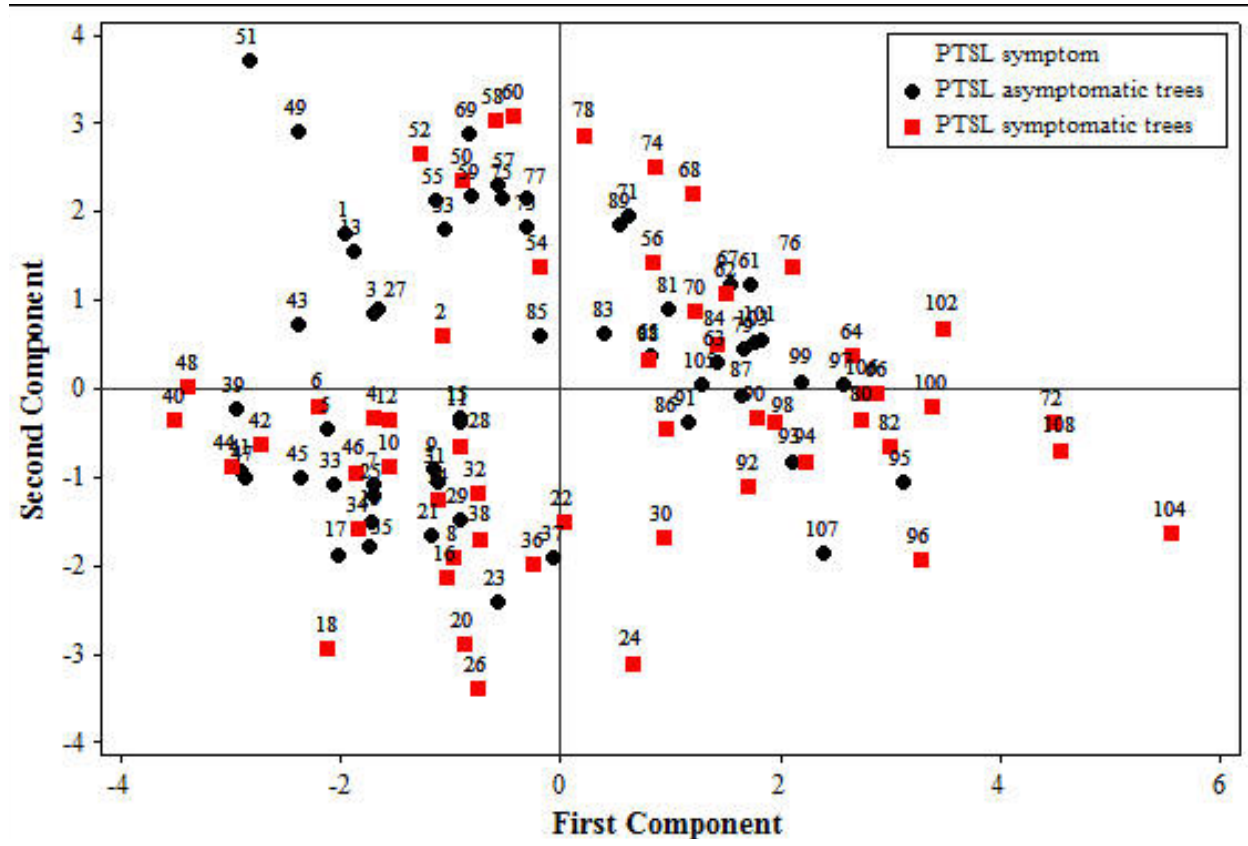

FIGURE 2- Scores of symptomatic and asymptomatic PTSL peach trees obtained by principal component analysis. Embrapa Clima Temperado, February 2015. 


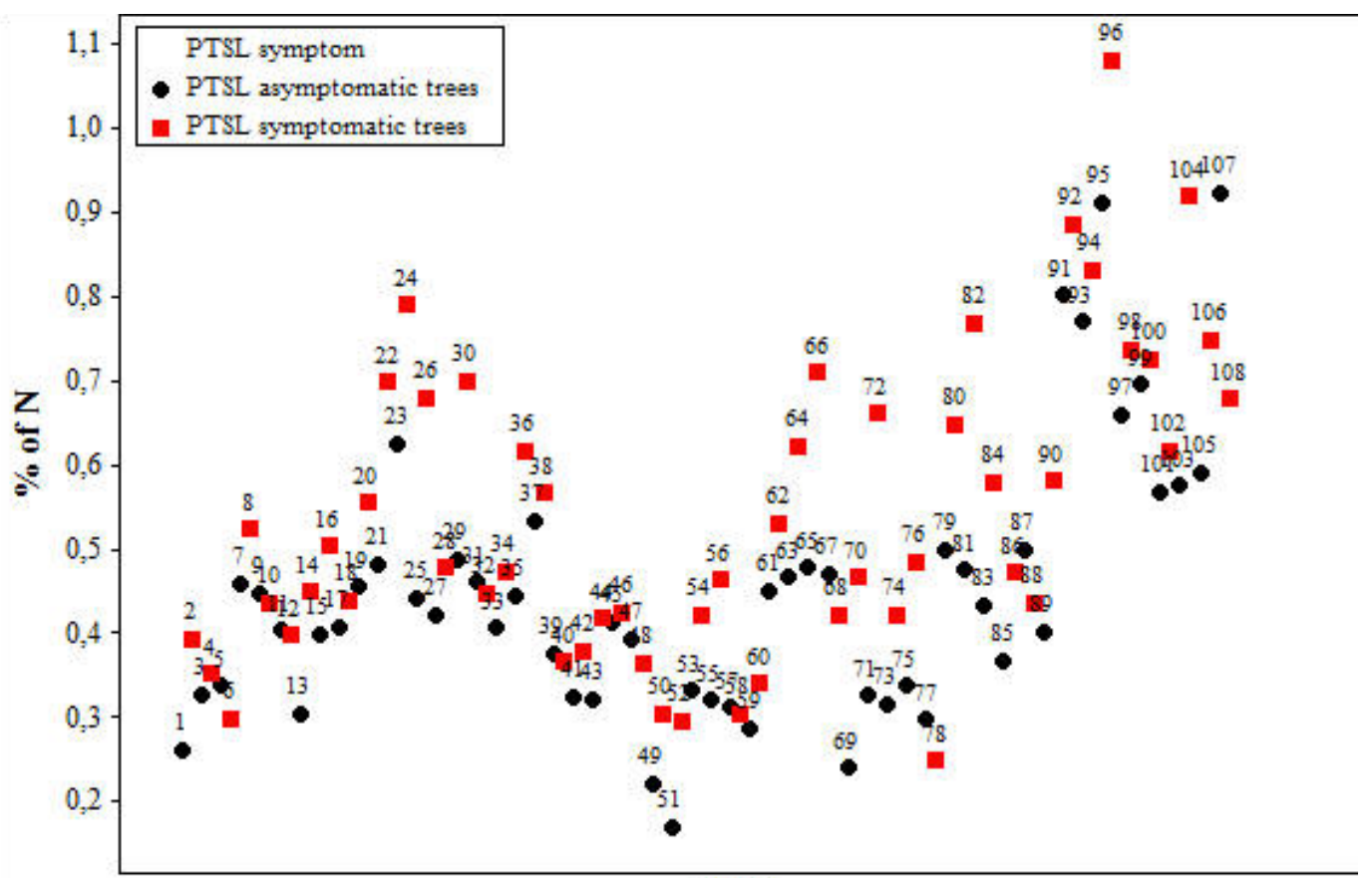

Trees

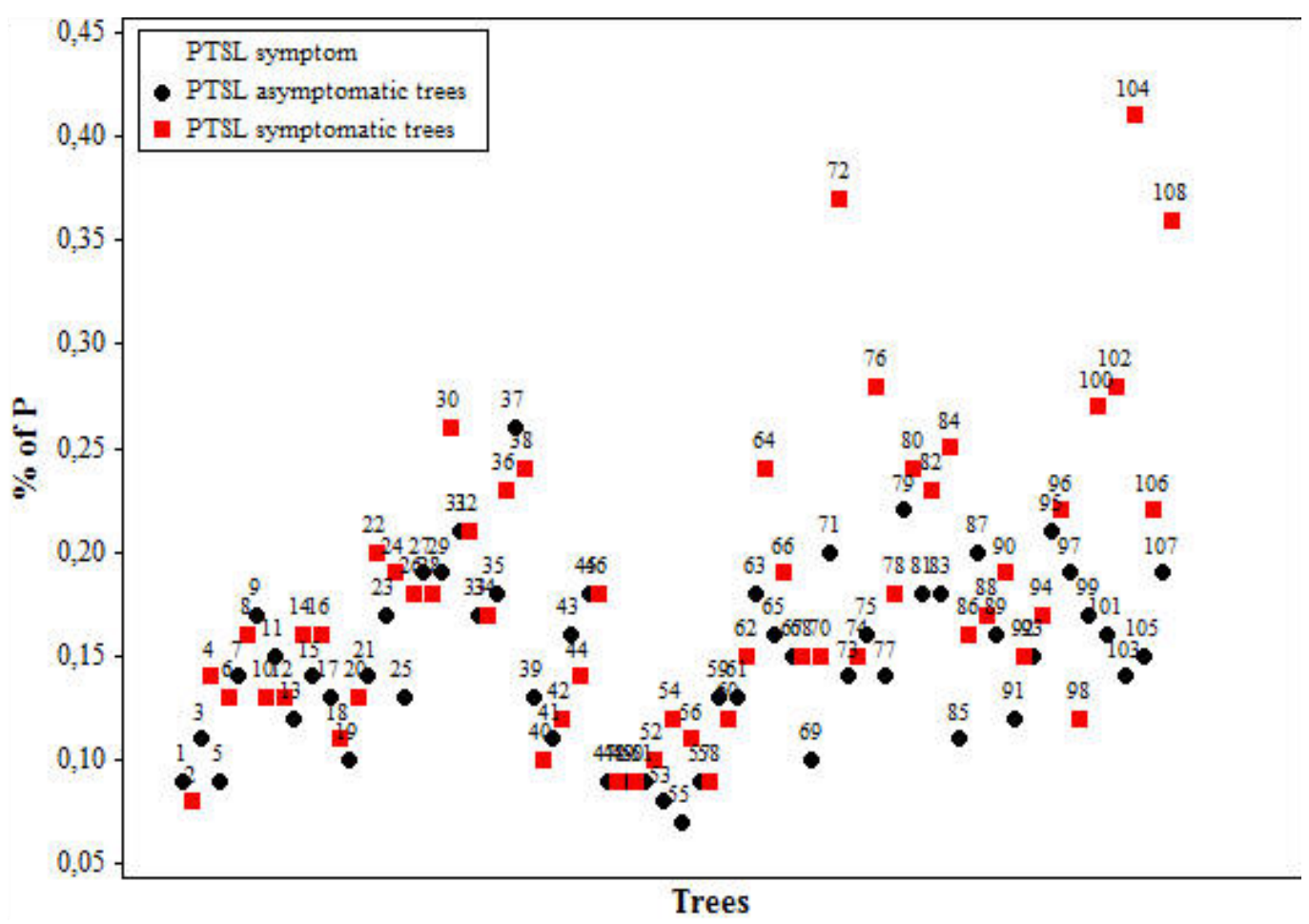

continue... 


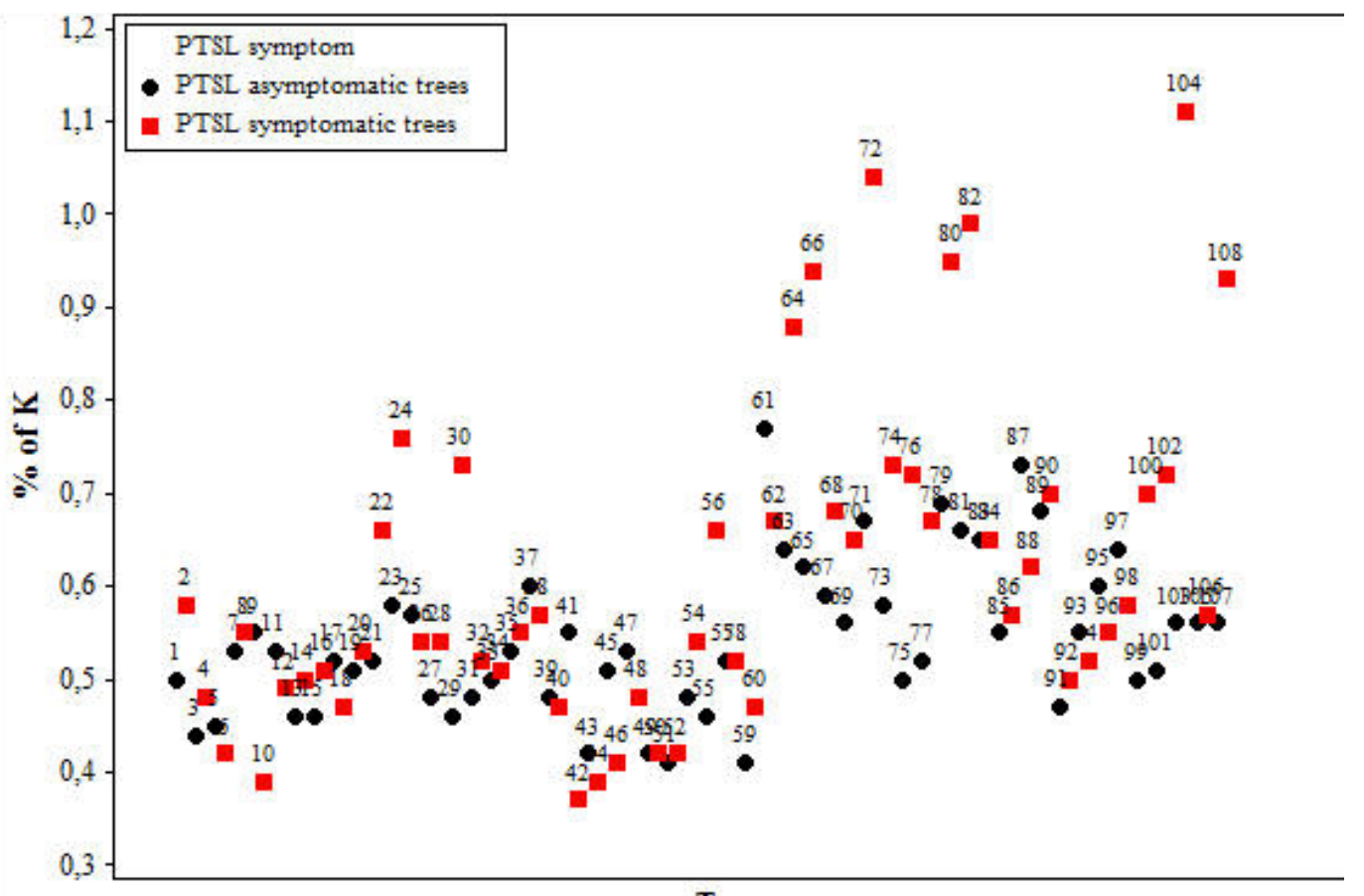

Trees

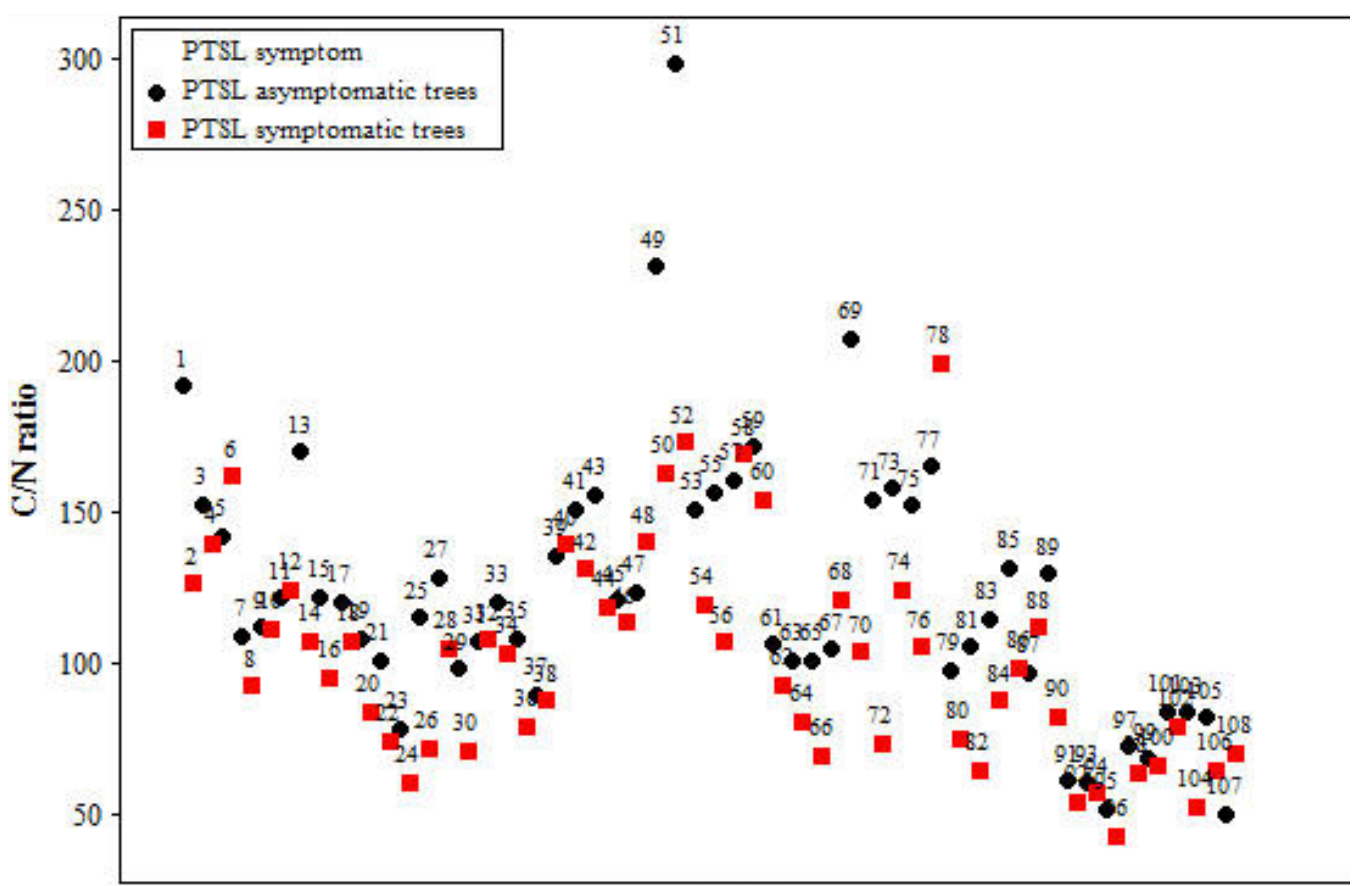

\section{Trees}

FIGURE 3- Scatter plots for variables that showed significance between groups of symptomatic and asymptomatic plants. Embrapa Clima Temperado, February 2015. 
TABLE 2 - Analysis of variance of variables evaluated in the bark of symptomatic and asymptomatic PTSL peach trees. Embrapa Clima Temperado, February 2015.

\begin{tabular}{cccc}
\hline Variable $^{(1)}$ & Symptomatic & Asymptomatic & p-value \\
\hline $\mathrm{C} \%$ & $49.2994 \pm 0.1946 \mathrm{a}$ & $49.3341 \pm 0.1886 \mathrm{a}$ & 0.8986 \\
\hline $\mathrm{N} \%$ & $0.5396 \pm 0.0244 \mathrm{a}$ & $0.4465 \pm 0.0216 \mathrm{~b}$ & 0.0051 \\
\hline $\mathrm{C} / \mathrm{N}(\mathrm{ratio})$ & $101.836 \pm 4.7221 \mathrm{~b}$ & $124.208 \pm 6.1296 \mathrm{a}$ & 0.0047 \\
\hline $\mathrm{P} \%$ & $0.1806 \pm 0.0098 \mathrm{a}$ & $0.1480 \pm 0.0056 \mathrm{~b}$ & 0.0045 \\
\hline $\mathrm{K} \%$ & $0.6128 \pm 0.0237 \mathrm{a}$ & $0.5411 \pm 0.0111 \mathrm{~b}$ & 0.0073 \\
\hline $\mathrm{Ca} \%$ & $1.3956 \pm 0.0610 \mathrm{a}$ & $1.4413 \pm 0.0421 \mathrm{a}$ & 0.5386 \\
\hline $\mathrm{Mg} \%$ & $0.1228 \pm 0.0035 \mathrm{a}$ & $0.1381 \pm 0.0190 \mathrm{a}$ & 0.4273 \\
\hline $\mathrm{Fe}\left(\mathrm{mg} \mathrm{kg}^{-1}\right)$ & $85.7593 \pm 5.8696 \mathrm{a}$ & $87.8704 \pm 5.4068 \mathrm{a}$ & 0.7919 \\
\hline $\mathrm{Mn}\left(\mathrm{mg} \mathrm{kg}^{-1}\right)$ & $32.2778 \pm 3.8000 \mathrm{a}$ & $32.4444 \pm 3.4331 \mathrm{a}$ & 0.9741 \\
\hline $\mathrm{Zn}\left(\mathrm{mg} \mathrm{kg}^{-1}\right)$ & $8.3333 \pm 0.8212 \mathrm{a}$ & $8.1481 \pm 0.7835 \mathrm{a}$ & 0.8707 \\
\hline $\mathrm{Cu}\left(\mathrm{mg} \mathrm{kg}^{-1}\right)$ & $35.7407 \pm 5.4196 \mathrm{a}$ & $36.6852 \pm 5.3119 \mathrm{a}$ & 0.9012 \\
\hline $\mathrm{B}\left(\mathrm{mg} \mathrm{kg}^{-1}\right)$ & $19.5741 \pm 0.5370 \mathrm{a}$ & $19.8889 \pm 0.5258 \mathrm{a}$ & 0.6761 \\
\hline
\end{tabular}

(1) $=$ Means followed by different letters in the same line differ by the Tukey test at $5 \%$ probability.

\section{CONCLUSIONS}

The principal component analysis of the studied variables did not allow the formation of distinct groups of symptomatic and asymptomatic PTSL plants.

Peach trees with visible PTSL symptoms have higher $\mathrm{N}, \mathrm{P}$ and $\mathrm{K}$ levels and lower $\mathrm{C} / \mathrm{N}$ ratio in the bark of the main scaffolds in the early sprouting period.

\section{ACKNOWLEDGMENTS}

The authors would like to thank CNPq and Embrapa for financial support; the Municipal Emater offices in Pelotas-RS and Canguçu-RS for the support and all the families of peach growers who accompanied and enabled this work.

\section{REFERENCES}

ALMALIOTIS, D.D.; MANGANARIS, A.G.; SIMONIS, A.D; BLADENOPOULOU, S.B. Rootstock effect on yield and mineral nutrition of 'Maycrest' peach trees under conditions of limeinduced chlorosis. Developments in Plant and Soil Sciences, Dordrecht, v.59, p.301-306, 1995.

BRITTAIN, J.A.; MILLER Jr., R.W. Managing peach tree short life in the Southeast. Clemson: Agricultural Extension Services of Georgia. 1978. 19p. (Circular, 585).
CAMPOS, A.D. Morte-precoce do pessegueiro: aspectos fisiológicos. Revista Brasileira de Fruticultura, Jaboticabal, v.14, n.1, p.227-229, 1992.

CAMPOS, A.D.; CARNEIRO, R.M.D.G.; GOMES, C.B.; MAYER, N.A. Morte precoce de plantas. In: RASEIRA, M.C.B.; PEREIRA, J.F.M.; CARVALHO, F.L.C. Pessegueiro. Brasília: Embrapa, 2014. p.509530.

CAO, T.; DUNCAN, R.A.; KIRKPATRICK, B.C.; SHACKEL, K.A.; DEJONG, T.M. Effect of calcium and nitrogen fertilization on bacterial canker susceptibility in stone fruits. Fruits, Paris, v.68, n.3, p.245-254, 2013.

CAO, T.; DUNCAN, R.A.; MCKENRY, M.V.; SHACKEL, K.A.; DEJONG, T.M.; KIRKPATRICK, B.C. Interaction between nitrogen-fertilized peach trees and expression of syrB, a gene involved in syringomycin production in Pseudomonas syringae pv. syringae. Bacteriology, Washington, v.95, n.5, p.581-586, 2005.

CARNEIRO, R.M.D.G.; FORTES, J.F.; ALMEIDA, M.R.A. Associação de Criconemella xenoplax com a morte do pessegueiro no Rio Grande do Sul. Nematologia Brasileira, Brasília, DF, v.17, n.2, p.122-131, 1993. 
HERTER, F.G.; MARAFON, A.C. Alterações morfo-fisiológicas em tecidos de pessegueiro e relação com a morte precoce de plantas. Pelotas: Embrapa Clima Temperado, 2007. 46p. (Boletim de Pesquisa e Desenvolvimento, 56).

JOHnSON, R.A.; WICHERN, D.W. Applied multivariate statistical analysis. Upper Saddle River: Prentice Hall, 2007.

JONES, T.L.; JONES, U.S. Influence of soil pH, aluminum and sulfur on short life of peaches trees growing on loamy sands in Southeastern United States. Florida State Horticultural Society, Lake Alfred, v.87, p.367-371, 1974.

\section{LECO Corp. Instruction Manual for TruSpec} CHN Determinators. 2005.

LUNA-GUERRERO, A.Y.; MONTES-BELMONT, R.; TALAVERA-RUBIA, M.F.; FLORESMOCTEZUMA, H.E.; BRAVO-LUNA, L. Estudio preliminar de los factores bióticos e abióticos asociados a la muerte del duraznero en Morelos, México. Nematropica, Auburn, v.41, n.2, p.254262, 2011.

MARAFON, A.C.; HERTER, F.G.; BACARIN, M.A.; HAWERROTH, F.J. Atividade da peroxidase durante o período hibernal de plantas de pessegueiro (Prunus persica (L.) Batsch.) cv. Jubileu com e sem sintomas da morte precoce. Revista Brasileira de Fruticultura, Jaboticabal, v.31, n.4, p.938-942, 2009.

MAYER, N.A; UENO, B. A morte-precoce do pessegueiro e suas relações com porta-enxertos. Pelotas: Embrapa Clima Temperado, 2012. 42p. (Documentos, 359).

MAYER, N.A.; UENO, B.; ANTUNES, L.E.C. Seleção e clonagem de porta-enxertos tolerantes à morte-precoce do pessegueiro. Pelotas: Embrapa Clima Temperado, 2009. 13p. (Comunicado Técnico, 209).

MILLARD, P. Internal cycling of nitrogen in trees. Acta Horticulturae, The Hague, n.383, p.3-14, 1995.
MUÑOZ, N.; GUERRI, J.; LEGAZ, F.; PRIMOMILLO, E. Seasonal uptake of ${ }^{15} \mathrm{~N}$-nitrate and distribution of absorbed nitrogen in peach trees. Plant and Soil, The Hague, v.150, p.263-269, 1993.

NYCZEPIR, A.P. Influence of Criconemella xenoplax and pruning time on short life of peach trees. Journal of Nematology, College Park, v.22, n.1, p.97-100, 1990.

NYCZEPIR, A.P.; OKIE, W.R. Occurrence of peach tree short life on a field site with no history of peach production. HortScience, Alexandria, v.31, n.1, p.163, 1996.

OKIE, W.R.; REIGHARD, G.L.; BECKMAN, T.G.; NYCZEPIR, A.P.; REILLY, C.C.; ZEHR, E.I.; NEWALL JR., W.C.; CAIN, D.W. Field-screening Prunus for longevity in the Southeastern United States. HortScience, Alexandria, v.29, n.6, p.673677, 1994.

REIGHARD, G.L.; MAYER, N.A.; GLENN, M.; BRIDGES, W. Carbon to nitrogen ratio in peach bark and incidence of bacterial canker. In: INTERNATIONAL HORTICULTURAL CONGRESS, 29., 2014, Brisbane. Anais... Brisbane: ISHS, 2014. p.1045.

REILLY, C.C.; NYCZEPIR, A.P.; SHARPE, R.R.; OKIE, W.R.; PUSEY, P.L. Short life of Peach Trees as related to tree physiology, environment, pathogens, and cultural practices. Plant Disease, Saint Paul, v.70, n.6, p.538-541, 1986.

RICCI, A.P.; MOURÃO FILHO, F.A.A.; ARAÚJO, P.S.R.; BERETTA, M.J.G.; DERRICK, K. Teores de nutrientes em laranjeiras 'Pêra' em função da clorose variegada dos citros. Laranja, Cordeirópolis, v.22, n.2, p.517-531, 2001.

RITCHIE, D.F.; CLAYTON, C.N. Peach Tree Short Life: a complex of interacting factors. Plant Disease, Saint Paul, v.65, n.6, p.462-469, 1981.

SHARPE, R.R.; REILLY, C.C. Elemental and chemical concentration in peach tree short life and healthy trees. Communications in Soil Science and Plant Analysis, New York, v.17, n.7, p.761774, 1986. 
SHARPE, R.R.; REILLY, C.C.; NYCZEPIR, A.P.; OKIE, W.R. Comparison of elemental concentrations between peach tree short life and healthy trees before and after tree death. Communications in Soil Science and Plant Analysis, New York, v.20, n.17-18, p.1753-1767, 1989.

SHIN, H.; KIM, K.; OH, Y.; YUN, S.K.; OH, S.I.; SUNG, J.; KIM, D. Carbohydrate changes in peach shoot tissues and their relationship to cold acclimation and deacclimation. The Horticulture Journal, Tokyo, v.84, n.1, p.21-29, 2015 b.

SHIN, H.; OH, Y.; KIM, D. Differences in cold hardiness, carbohydrates, dehydrins and related gene expressions under an experimental deacclimation and reacclimation in Prunus persica. Physiologia Plantarum, Lund, n.154, p.485-499, 2015a.

TEDESCO, M.J.; GIANELLO, C.; BISSANI, C.A.; BOHEN, H.; VOLKWEISS, S.J. Análises de solos, plantas e outros materiais. 2. ed. Porto Alegre: UFRGS, 1995. 174p.
THOMAS, F.M.; BLANK, R. The effect of excess nitrogen and of insect defoliation on the frost hardiness of bark tissue of adult oaks. Annals of Forest Science, Les Ulis, v.53, p.395-406, 1996.

VARIAN. Analytical methods for flame atomic absortion spectrometry.

2006. 145 p.

WEHUNT, E.J.; HORTON, B.D.; PRINCE, V.E. Effects of nematicides, lime, and herbicide on peach tree short life in Georgia. Journal of Nematology, College Park, v.12, n.3, p.183-189, 1980.

WERNER, D.; PARKER, M.L.; WHEELER, E. Potential relationship between peach tree short life symptomatology and aberrant wood anatomy. HortScience, Alexandria, v.30, n.4, p.786-787, 1995. 